\title{
THE EFFECT OF ORGANIC OSMOPROTECTORS ON AEROMONAS TROTA AND A. HYDROPHILA GROWN UNDER HIGH SODIUM CHLORIDE CONCENTRATIONS
}

\author{
Ana Paula L. Delamare ${ }^{1,2 *}$; Thais Dalcin ${ }^{1}$; Gabriela Müller ${ }^{1}$; Sergio Olavo Pinto da Costa $^{1,2}$; Sergio Echeverrigaray ${ }^{1}$ \\ ${ }^{1}$ Laboratório de Biotecnologia Vegetal e Microbiologia Aplicada, Instituto de Biotecnologia, Universidade de Caxias do Sul, \\ Caxias do Sul, RS, Brasil. ${ }^{2}$ Instituto de Biociências, Universidade de São Paulo, São Paulo, SP, Brasil.
}

This paper corresponds to an "extended abstract" selected for oral presentation in the $22^{\text {nd }}$ Brazilian Congress of Microbiology, held in Florianópolis, SC, Brazil, in November 17-20, 2003

\begin{abstract}
The effect of organic solutes on the growth of Aeromonas trota and A. hydrophila was evaluated. Proline and glutamic acid were not effective as osmoprotectors, but betaine exerts osmoprotection allowing the growth of both strains in inhibitory concentrations of $\mathrm{NaCl}$. Growth kinetics suggests that the halotolerance difference between the strains is associated with the synthesis of osmolytes rather than betaine uptake.
\end{abstract}

Key words: halotolerance, betaine, Aeromonas.

\section{INTRODUCTION}

Aeromonas are opportunistic pathogens of fishes, reptiles and humans responsables for gastroenteritis, endocarditis, and septicemia, among other disease (1). Many reports have shown that the human diarrheia caused by these bacteria are related to the ingestion of contaminated food and water (1). Their importance as foodborne bacteria increase due to their ability to survive and grow under the low temperatures and high sodium chloride concentrations commonly used in food preservation $(1,2,4)$. Salt tolerance in bacteria is associated to increase of the intracellular concentration of certain solutes, ensuring that the internal osmolarity is always higher than the external, and that the cell turgor is therefore maintained. These solutes can be synthesized by the bacteria (osmolytes) or obtained from the medium (osmoprotectors) $(3,5,6)$. The aim of this study was to evaluate the effect of different osmoprotectors on the growth Aeromonas trota and A. hydrophila under high salt concentrations.

\section{MATERIALS AND METHODS}

The bacterial strains used in this study were Aeromonas trota (ATCC49657), a salt tolerant strain, and A. hydrophila
(ATCC7966), a type strain with intermediary salt tolerance. The bacteria were maintained on Trypticase Soy Agar (TSA) medium. All the experiments were conducted on M9 medium supplemented with $0.08,0.51$ or $0.85 \mathrm{M}$ sodium chloride, and different concentrations of proline, glycine, betaine, glutamic acid, glycerol, and yeast extract. Before each experiment the bacteria were cultured at three times on M9 medium to avoid the interference of TSA components. The experiments were conducted at $30^{\circ} \mathrm{C}$ in orbital shaker (100 rpm). Cell growth was evaluated by optical density measurements at $540 \mathrm{~nm}$ on a Pharmacia Utrospec 1000 spectrophotometer. Cell viability was determinated by plating and colony counting on TSA medium.

\section{RESULTS AND DISCUSSION}

Initially, we evaluated the effect of four aminoacids (proline, glycine, glutamic acid, and proline), a polyalcohol (glycerol), and a complex substrate (yeast extract), on the growth of $A$. trota and A. hydrophila. The results presented in Fig. 1 showed that only betaine and yeast extract confers, to both bacterial strains, the ability to grow under high salt concentration. Betaine osmoprotective effect has been reported on several bacterial species $(5,6,7)$. In E. coli, intracellular betaine accumulation

*Corresponding author. Mailing address: Laboratório de Biotecnologia Vegetal e Microbiologia Aplicada, Instituto de Biotecnologia, Universidade de Caxias do Sul. Rua Francisco Getúlio Vargas, 1130. 95001-970, Caxias do Sul, RS, Brasil. E-mail: aplongar@yahoo.com 


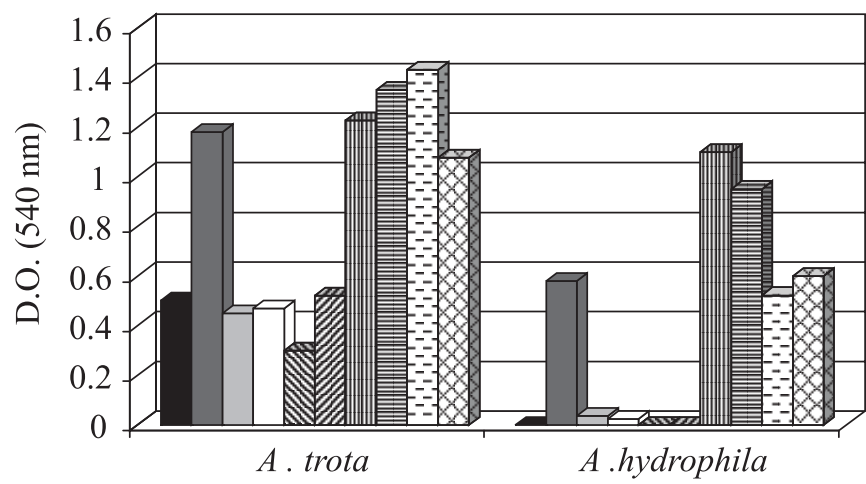

Figure 1. Effect of organic solutes on the growth of $A$. trota (ATCC49657) and $A$. hydrophila (ATCC7966) on M9 medium with $0.51 \mathrm{M} \mathrm{NaCl}$. Control $\square, 1 \mathrm{mM}$ betaine $\square, 1 \mathrm{mM}$ glycine $\square, 1 \mathrm{mM}$ proline $\square, 0.05 \%$ glycerol $\square, 1 \mathrm{mM}$ glutamic acid $\mathbf{\Xi}$, $0.5 \%$ yeast extract $\mathbf{m}, 1 \mathrm{mM}$ betaine $+1 \mathrm{mM}$ glycine 冒, $1 \mathrm{mM}$ betaine $+1 \mathrm{mM}$ proline $\mathrm{E}-\mathrm{-}$ and $1 \mathrm{mM}$ betaine $+1 \mathrm{mM}$ glutamic acid囚.
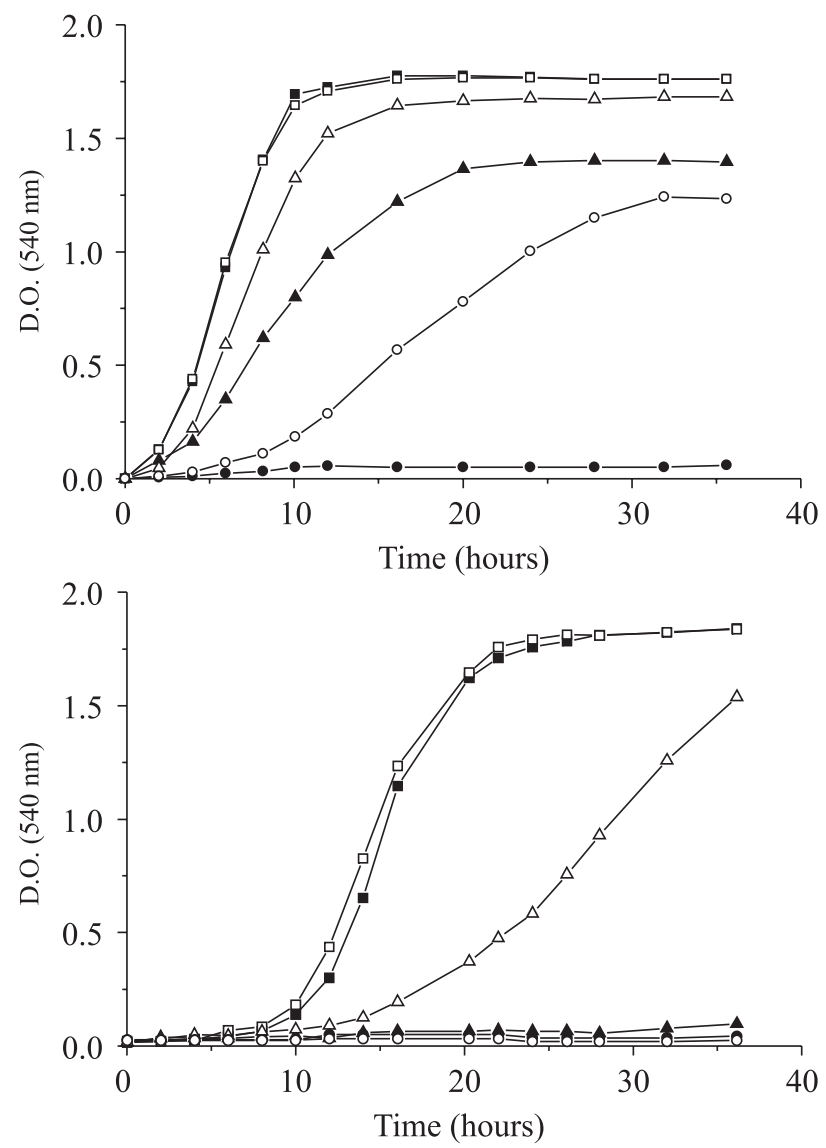

Figure 2. Growth cinetics of Aeromonas trota ATCC49657 (A) and A. hydrophila ATCC7966 (B) on M9 medium with $0.08 \mathrm{M} \mathrm{NaCl}(\square), 0.08 \mathrm{M} \mathrm{NaCl}$ and $1 \mathrm{mM}$ betaine $(\square), 0.51 \mathrm{M}$ $\mathrm{NaCl}(\mathbf{\Delta}), 0.51 \mathrm{M} \mathrm{NaCl}$ and $1 \mathrm{mM}$ betaine $(\triangle), 0.85 \mathrm{M} \mathrm{NaCl}(\bigcirc)$, and $0.85 \mathrm{M} \mathrm{NaCl}$ and $1 \mathrm{mM}$ betaine $(\mathrm{O})$. depends on its synthesis from choline (6), or its uptake from the medium mediated by the ProU system (3). The protective effect of yeast extract is probably due to the synergistic effect of several components like potassium salts, glutamic acid, proline, trehalose, and glycerol.

Experimental data showed that the protective effect of betaine depends on its concentration with an optimum between 0.1 and $1 \mathrm{M}$. In this range, the protective effect is directly proportional to salt concentration. Very high concentrations of betaine $(>3 \mathrm{M})$ resulted in bacterial growth depletion.

Data shown in Fig. $2 \mathrm{~A}$ and $\mathrm{B}$, confirmed the osmotolerance of $A$. trota to $0.51 \mathrm{M} \mathrm{NaCl}$, and the sensibility of $A$. hydrophila to high salt concentrations. In Fig. $2 \mathrm{~A}$ it can be observed that betaine $(1 \mathrm{mM})$ stimulate the growth of $A$. trota in the presence of $0.51 \mathrm{M} \mathrm{NaCl}$ doubling its growth rate, and allowing its growth on $0.85 \mathrm{M} \mathrm{NaCl}$. Similar results were obtained with $A$. hydrophila on $0.51 \mathrm{M} \mathrm{NaCl}$. These data suggest that the difference observed in the halotolerance of these bacteria is associated with the synthesis of osmolytes rather than the transport and accumulation of osmoprotectors.

\section{ACKNOWLEDGEMENTS}

We thanks UCS for the financial support, and CAPES and $\mathrm{CNPq}$ for scholarships.

\section{RESUMO \\ Efeito de osmoprotetores orgânicos sobre Aeromonas trota e $A$. hydrophila cultivada em concentrações de cloreto de sódio}

O efeito de solutos orgânicos no crescimento de Aeromonas trota e A. hydrophila foi avaliado. A prolina e o ácido glutâmico não apresentaram efeito osmoprotetor, mas a betaina exerceu osmoproteção permitindo o crescimento de ambas bactérias em concentrações inibitórias de $\mathrm{NaCl}$. A cinética do crescimento sugere que a diferença em halotolerância entre as linhagens está associada à síntese de osmolitos, mais do que à capacidade de acúmulo de betaina.

Palavras-chave: halotolerância, betaina, Aeromonas.

\section{REFERENCES}

1. Austin, B.; Altwegg, M.; Gosling, P.J.; Joseph, S.W. The genus Aeromonas. John Wiley and Sons, New York, NY., 1996, p. 344.

2. Delamare, A.P.L.; Costa, S.O.P.; Silveira, M.M.; Echeverrigaray, S. Growth of Aeromonas species on increasing concentrations of sodium chloride. Lett. Appl. Microbiol., 30:57-60, 2000.

3. Grothe, S.; Krogsrud, R.L.; McClellan, D.J.; Milner, J.L.; Wood, J.M. Proline transport and osmotic stress response in Escherichia coli K12. J. Bacteriol., 166:253-259, 1986. 
4. Knochel, S. Growth characteristics of motile Aeromonas spp. isolated from different environment. Int. J. Food Microbiol., 10:235-244, 1990.

5. Le Rubulier, D.; Strom, A.R.; Dandekar, A.M.; Smith, L.T.; valentine, R.C. Molecular biology of osmoregulation. Science, 224:1064-1068, 1984.
6. Robert, H.; Le Marrec, C.; Blanco, C.; Jebbar, M. Glycine betaine, carnitine, and choline enhance salinity tolerance and prevent the accumulation of sodium to a level inhibiting growth of Tetragenococcus halophila. Appl. Environ. Microbiol., 66:509-517, 2000.

7. White, D. The physiology and biochemistry of prokaryotes. Oxford Univ. Press, NY, 2000, p.566. 